doi: $10.18575 /$ msrs.sm.e.18.08 UDC: $615.2 .076: 616-056.7$ COBISS.RS-ID: 7318040

\title{
Clinical Trials and the Importance of Biobanks in Rare Diseases
}

\begin{abstract}
Rare diseases ("orphan diseases") (RDs) count for 5000-8000 diseases with low prevalence and most commonly of genetic origin. Although most of rare diseases are manifested in early childhood, many are diagnosed in adults, even in elderly. Common characteristics, such as severity, debilitating and life-threatening features, with the lack of a specific drugs, make the treatment of RD a significant public-health problem. Even though randomized controlled trials (RCTs) are the most ideal design for evaluating new drugs, the aim of this review was to present the aggravating circumstances that development of so-called orphan drugs faces in context of RD. We searched the PubMed/Medline for publications on studies and ethics in RDs and applying of "omics" technologies in analysing tissue samples at biobanks published between 2010 and 2017. In this review, we presented the most significant obstacles in conducting clinical trials in $\mathrm{RD}$ as well as main alternative clinical trial designs aiming to decrease the number of patients recruited with increased access to innovative medicines as many as possible. Furthermore, we have presented the possibility of accessing innovative drugs outside of clinical trials as well as ethics violations by the involvement of the subject in clinical trial. Modern technologies in molecular biology will enable the development of „precision medicine“ aimed at identifying the best therapeutic goal, depending on the genetic and epigenetic factors in the affected person. That is why RD biobanks have great significance in the preservation and distribution of tissue samples, in the research of diagnostic biomarkers and the drug development.
\end{abstract}

Key words: rare diseases, "orphan drugs", ethics/ethical, biobanks

(Scr Med 2018:49:49-56)

\section{Lana Nežićt, Vesna Vujić-Aleksić ${ }^{1,2}$, Marina Dukić, Aleksandra Đeri ${ }^{3}$}

${ }^{1}$ Department of Pharmacology, Toxicology and Clinical Pharmacology, Faculty of Medicine, University of Banja Luka,

${ }^{2}$ Agency for Accreditation and Healthcare Quality Improvement in Republic of Srpska,

${ }^{3}$ Department of Endodontics, Division of Dental Medicine, Faculty of Medicine, University of Banja Luka,

\section{Contact address:}

Lana Nežić

Street address: Save Mrkalja 14

78 ooo Banja Luka

Republic of Srpska

Bosnia and Herzegovina

e-mail: lana.nezic@med.unibl.org

phone number: +387-51-234-101
Submitted: March 2 ${ }^{\text {nd }}, 2018$ Accepted: March 11 ${ }^{\text {th }}, 2018$

\section{Introduction}

Today, it is known between 5000 and 8000 different rare diseases (RDs), which affect 6-8\% of the population. According to the definition of the European Organization for rare diseases (EURORDIS), a RD has a prevalence of at least 1 affected to 2000 persons..$^{1,2}$ Occasionally the term "orphan" is used instead of "rare", to emphasize the public's attention and scientific community to RDs.
Based on their common characteristics (Table 1), ${ }^{1,2} \mathrm{RDs}$ represent a complex challenge in the treatment, research and drug development ("orphan drugs").

As RDs are recognized as public health problem, The Ordinance on rare diseases, issued by European Medicines Agency (EMA) (European Parliament, EC 141/2000, 847/2000) and the 1983 Medicines 
Act for rare diseases in the United States, intensively support development of innovative drugs for RD through various projects (eg. Framework programs, FP 6-7, Horizon2020) and support pharmaceutical

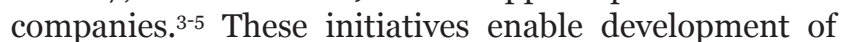
new drugs and give opportunities to treat RDs based on scientific evidence (evidence-based medicine), instead of "eminence-based medicine" treatments so far. ${ }^{6}$ However, drug development for RDs in comparison to other clinical trials faces additional specific challenges and barriers. The aim of this manuscript was to present the characteristics and the most common obstacles in conducting clinical trials with "orphan drugs", proposed new designs these clinical trials, and availability of biological samples for the research of rare diseases. In our study, we considered scientific publications in PubMed/Medline (2010-2017 period) with the chosen keywords: "rare diseases", "orphan drugs", "clinical trials", "ethics / ethics issues", "biobanks".

Table 1. Common Characteristics of Rare Diseases ${ }^{1,2}$

\begin{tabular}{|c|c|}
\hline $\begin{array}{l}\text { Low disease } \\
\text { prevalence }\end{array}$ & $<1$ patient/2000 inhabitants \\
\hline $\begin{array}{l}\text { Diverse etiological } \\
\text { causes }\end{array}$ & $\begin{array}{l}80 \% \text { genetic origin. } \\
\text { Other rare disease are not entirely caused by gene mutation, such as follows: metabolic, } \\
\text { autoimmune,. neuromuscular, neurodegenerative, congenital anomalies, dysmorphia, rare } \\
\text { carcinoma. } \\
\text { Not preventable. } \\
\text { Screening programmes can be used in identification risk and probability of rare disease inheritance. }\end{array}$ \\
\hline $\begin{array}{l}\text { Manifestation in } \\
\text { across different age } \\
\text { groups }\end{array}$ & $\begin{array}{l}\text { Most (approx. } 75 \%) \text { are manifested in early childhood. } \\
\text { (4-5\% newborns and infants). } \\
\text { Others can be manifested in adult or elder patients. }\end{array}$ \\
\hline Delayed diagnosis & $\begin{array}{l}\text { Insufficient knowledge about a particular rare disease. } \\
\text { Required multidisciplinary approach and coordination within health system. } \\
\text { Unavailable specific diagnostics for the most of rare disease (70\%). } \\
\text { Expensive and unavailable diagnostics in low-income countries. }\end{array}$ \\
\hline $\begin{array}{l}\text { Various disease } \\
\text { course }\end{array}$ & $\begin{array}{l}\text { Chronic, progressive diseases, various clinical forms, various prognosis. } \\
\text { Disease course can be fulminant. } \\
\text { Impaired quality of life } \\
\text { (limited daily activities, disability, cognitive decline). }\end{array}$ \\
\hline Disease complexity & $\begin{array}{l}\text { Affects organ and/or entire organ system. } \\
\text { Progress and affects several organ systems. } \\
\text { Life-threatening. } \\
\text { Incurable diseases. }\end{array}$ \\
\hline
\end{tabular}

\section{An overview of characteristics and obstacles in conducting clinical trials of drugs in rare diseases}

In general, conduction of randomized, placebo-controlled clinical trials as a "gold standard" in drug development, faces great difficulties in RDs (Table 2). ${ }^{2,5,7,10}$

A small sample size of patients distributed worldwide (eg, a few to 100 patients in the world) prevents the implementation of multi-centric studies that provide strong scientific evidence. Furthermore, RDs may be slow progressive with a wide spectrum of phenotypic manifestations (clinical symptoms), which make difficult to form a group of participants with a similar clinical form, monitor course a disease, define and measure endpoints.

Rare diseases are most commonly diagnosed in childhood, which, depending on the type of disease, increase ethical issues for participation in the trial (giving assent or consent for participation). In addition, use of placebo is ethically unacceptable neither in parallel design of clinical trials in life-threatening diseases, nor in crossover, in a trial arm without investigated or standard treatment (non-drug period). ${ }^{2,5,7-10}$ For a large number of RDs, there are not adequate experimental models of disease that results in insufficient data of efficacy and 
drug safety originated in preclinical research (e.g. acute, chronic, reproductive toxicity and carcinogenicity), and consequently presents a certain risk in the selection of the first dose for clinical clinical trials.

Table 2. The Most Frequent Issues in Conducting Randomized Clinical Trials in Rare Diseases ${ }^{2,5}$

\begin{tabular}{ll} 
Lack of preclinical disease model & Lack/incomplete preclinical data of investigational drug efficacy and safety \\
& Risk in selection of,first-dose in human“ dose in clinical trials \\
Feasibility & Low number of participants/patients and wide geographical distribution that \\
& complicate enrollment in clinical trials \\
& Diversity in clinical forms and diseases stage. \\
Heterogeneity in participants`sample & Participants/patients are of different age group. \\
& Variability of genuine disease course and prognosis. \\
& Lack of specific diagnostic tests to monitor disease course. \\
Lack of reliable parameters/endpoints & Diversity of diseases clinical manifestations of diseases and eligible patients, \\
for disease monitoring & complicate defining and assessment of „endpoints“ in clinical trials. \\
& Limited possibilities in conducting randomized, placebo control trials, or „cross- \\
over“ studies with placebo arm. & Vulnerable population of patients. \\
\hline
\end{tabular}

Observational studies, such as cohort studies, can only contribute to simple research questions such as epidemiology and natural course of a disease, or in identification of risk factors of disease deterioration. Herewith, cohort studies help in evaluation of offlabel drug use (only when no other treatment options available) or symptomatic therapies (e.g. perception of patients and physician regarding the use of symptomatic drugs in amyotrophic lateral sclerosis (ALS), or offlabel application of lithium in ALS). However, often the impossibility to form other, un-exposed cohort; then the variable course of a disease, make results of cohort studies scientifically less important. ${ }^{2,11}$

Case-control studies may be a possibility for drug development, only in those RDs that have long latent period or where the study endpoints are sporadic (eg. rare acute disease)..$^{2,11}$

\section{Alternative designs of clinical trials in rare diseases}

Although conventional clinical trials provide the strongest scientific evidence, in RDs research, an alternative (non-conventional) design is being employed to ensure "proof of concept" trial with a small study sample and enhanced participants recruitment in an treatment arm (Table 3). Additionally, in successful conduction of research in a small number of participants, selection of surrogate endopoints is of great importance. A surrogate endopoints refer to biomarkers that substitute some clinical parameters (e.g. the frequency of epileptic attacks), and which are expected to have the ability to predict benefit (or damage) of the applied intervention. ${ }^{2}$, 7,8

Trials with historical controls need approximately fourfold fewer participants compared with a traditional twoarm trial with a concurrent control group.

Although the problem of recruitment is overcome in this design, this approach remains biassed quality and reliability of the results with respect to the confusing variables (e.g. different treatment in observed periods, lack of blindness, blinization). These contribute to the the incorrect assessment of interventional effects of investigated drugs. ${ }^{2}$

Cross-over design are controlled studies in which each participants receives study medications (tested and comparable / standard medicine without placebo), in different consecutive periods, with an appropriate washout period. Cross-over studies are probably the best design for studying chronic diseases, particularily as they are feasible in a small number of patients that serve as their own controls, along with ethical justification, as patients receive all study medications throughout the study. However, lack of blindness in the study may lead to bias in evaluating the drug investigated, while a long "wash-out" period may expose the participants to worsening of the disease..$^{2,7,8,11}$

$N$-of-1 design is a variant of a single cross-over (only one patient) trial. In this trial, the only one patient is included and exposed to experimental and control treatments, several times (N number), with "wash- out "periods. The 
main purpose of this study is the individual assessment of investigated drug, and in terms of $\mathrm{RD}$, there are obstacles in the requirement for a certain number of patients. However, this design requires stable state at the beginning of each investigational/treatment period. Although, these designs do not provide statistical power, multiple $N$-of-1 trials are in fact case studies. ${ }^{2,7,8,11}$

Table 3. Alternative Designs to Conventional, Randomized, Clinical Trials in Rare Diseases²

\begin{tabular}{|c|c|c|}
\hline Study design & Description & Purpose \\
\hline $\begin{array}{l}\text { Use of historical controls } \\
\text { (instead of a concurrent } \\
\text { control group) }\end{array}$ & $\begin{array}{l}\text { "Artificial" control group obtained from data of } \\
\text { patients databases or registries }\end{array}$ & Minimize sample size \\
\hline "Cross over" design & $\begin{array}{l}\text { Use of participants as their own controls. } \\
\text { Access to standard (if any) or investigational drug } \\
\text { throughout study. }\end{array}$ & $\begin{array}{l}\text { Minimize sample size } \\
\text { Maximize participants recruitment } \\
\text { due to increased access of receiving } \\
\text { treatments }\end{array}$ \\
\hline$N$-of-1 design & $\begin{array}{l}\text { Trial of a single patient randomized to alternately } \\
\text { receive different treatments at different }(N) \text { times. }\end{array}$ & $\begin{array}{l}\text { Minimize sample size } \\
\text { Assessment of therapeutic response for } \\
\text { individual patients }\end{array}$ \\
\hline Adaptive design & $\begin{array}{l}\text { Modifications of trial protocol (e.g., sample size, } \\
\text { randomization ratio, number of treatment arms), } \\
\text { based on interim analyses. }\end{array}$ & $\begin{array}{l}\text { Minimize sample size } \\
\text { Maximize recruitment of participants } \\
\text { receiving potential effective treatment } \\
\text { Adapted randomization in accordance } \\
\text { to treatment response and/or } \\
\text { probabilities to patient characteristics. }\end{array}$ \\
\hline Delayed start design & $\begin{array}{l}\text { Patients are continuously enrolled in trial, starting } \\
\text { a different time points, until a conclusion, positive } \\
\text { or negative, about the investigational drug is } \\
\text { reached. }\end{array}$ & $\begin{array}{l}\text { Minimize sample size } \\
\text { Time and cost saving }\end{array}$ \\
\hline
\end{tabular}

A delayed start design is also known as a "placebophase" or "open ended" randomized clinical study, and is conducted when participation in control group are unacceptable for patients and treating. Participants are recruited during the study at different time points starting either with investigational drug (one group receives drug as soon as they are enrolled (early start group), while the other (delayed start group) gets the placebo and after a certain period switch to the investigational drug). All participants are enrolled in the study until a positive or negative results are reached, and an assessment of drug efficacy and safety can be performed. However, large variations in the length of drug administration affect the statistical power of study results. ${ }^{2,12}$

Adaptive (flexible, Bayesian design) study design involves the modification of key study protocol features (sample size, randomization, length of drug administration) that depends on interim analyzes (data analysis during the test). These analyzes are particulary important in studies for RDs, as they can lead to an increased number of participants receiving investigational drug (responseadaptive randomization), or provide evidence for a premature interruption the trial due unacceptable drug safety. ${ }^{2,13}$

In conclusion, the number of participants, duration of study, clinical symptoms and fluctuation of disease course will influence on selected study design. In many RDs trials, more than one design can be employed taking into account all previously gained data that improve the statistical strength of the study results.

\section{Compassionate drug use in rare diseases}

In the context of the development of drugs for RDs, it is necessary to mark the compassionate use program (CUP). According to the EU Regulation 726/2004, Article 83.2, the CUP is defined as a procedure for medicinal product in treating chronic and/or serious, life-threatening 
disease that cannot be treated with approved medicines; administered drug is undergoing clinical trials or is in the process of obtaining a marketing authorization (early access program).$^{14}$ Most common, compassionate drug use is considered in later phases of clinical trials (Phase III), although is possible even earlier, in order to "bridge" the period between completion of trial and approval for marketing authorization by regulatory agencie. ${ }^{15}$ Only patients who do not meet defined criteria for participation in a clinical trial may receive a drug within the CUP without exposing them, for example, to a placebo group. ${ }^{16}$ It is important to emphasize that compassionate drug use in RDs can be carried out along to the clinical trials, but investigational drug within CUP is not intended for testing in patients (does not use placebo, or comparative drugs). Nevertheless, CUP represents a source of data on efficacy and drug safety in "real life". Besides, CUP does not represent "off-label" drug use (approved drug for another indication/age group), it is not a humanitarian or financial aid of pharmaceutical companies; nor marketing promotion is allowed to reach faster marketing authorisation for given drug. ${ }^{17}$

Similar to CUP, there is an additional possibility in the European Union (EU) for development a drug outside the clinical trial. This approach is intended for a single patient (named patient program), on the basis of a doctor's request to a pharmaceutical company. Although EMA has issued the EU Regulation 726/2004, and member states can develop their own CUP, this program is not obligatory. Thus, for example, Britain, Ireland and Sweden do not have a formal, while Hungary does not have a CUP at all. It is therefore necessary for doctors, patient associations, pharmaceutical companies and policy makers to participate in the creation of the CUP in order to provide access to innovative therapies. According to the EMA data, since 2006, 50 applications for CUP were registered, of which 17 were for RDs. A positive example illustrates activities of European and national associations patients with Gaucher's disease, which provided treatment even to the patients outside the EU, such was the case in Bosnia and Herzegovina. ${ }^{14,17,18}$

\section{Ethical considerations of clinical trials of drugs for rare diseases}

Although clinical trials are one of the best regulated areas of research, regulation that determines ethics principles in drug development for RDs is still insufficient. For the assessment of efficacy and safety of an "orphan drug", optimal approach would be benefit/risk analysis, instead of additional cost/benefit analysis claimed by pharmaceutical companies that invest in drug research. This can partially explain reduced interest in the investment to drug development for RDs. ${ }^{19,20}$ In addition,
RDs studies often question the basic principles of ethics: nonmaleficence (do no harm), beneficence, autonomy and dignity, and justice.

The principle of well-being and nonmaleficence (do no harm) is endangered in these studies for the following reasons: pharmacological active substances are often administered to participants even their efficacy and safety are not proved in preclinical studies (lack of an adequate model of disease), or participants consent to use drug within CUP. Secondly, low prevalence, or progressive course of some RDs, make impossible carrying out, and ethically unacceptable to have a placebo-controlled group of participants. ${ }^{21,22}$

The principle of autonomy and dignity is questioned in a community where treatment cost is high, and participation in clinical trials is the only way to access a potential drug. The fact that most of RDs occur in early childhood and that patients are unable to decide for their interest (the inability to give consent to participate in the study) makes them vulnerable. The vulnerability of these participants is particularly empahisized if cognitive impairment of children, adults and the elderly develop due to disease progression, which then may be relatively or absolutely incapable to consent to participate in the study.

The principle of justice is most often endangered because the criteria for participation in clinical study are strictly defined and without the possibility to adapt to respondents needs that prevents inclusion of seriously ill or patients with progressive disease. ${ }^{21,22}$

Herewith, ethical dilemmas raise genome research in patients ' tissue samples obtained during clinical trial that requires access to genetic material and information. Therefore, carriers of a gene mutation for a particular diseases or patients are faced with the potential violated privacy of their relatives by disclosure their genetic information. The rationale for disclosure of genetic information is only for recessive gene carriers for a particular disease, in their reproductive period and in offspring planning. ${ }^{19}$

\section{The importance of biobanks the development of drugs for rare diseases}

Biobanks (biorepository) are one of the most important parts in the development of translation research in predictive, personalized and precision medicine (PPPM). Biobanks that meet quality and safety criteria represent an infrastructure that assures a link between biological samples, registries of patients and clinical data. ${ }^{23,24}$ Today, biobanks networks have a significant role 
worldwide, out of them pan-european platforms such as European Research Infrastructure Consortiums (ERICs) and Biobanking and BioMolecular Resources Research Infrastructure (BBMRI-ERIC) are the most important. These networks create guidelines for good practise in biobanks, ethical, legal and social issues (Ethical, Legal, Social Issues, ELSI) in order to facilitate exchange of samples and of research results across Europe.5,25,26

According to Orphanet database (www.orpha.net), today there are 120 biobanks for RDs worldwide. These RDs biobanks may be foucus only on one disease such as the Progeria Research Foundation Cell and Tissue Bank, brain developmental anomalies of the National Institute of Child Health and Human Development Brain and Tissue Bank, or on tissue culture "Munich Tissue Culture Collection ", or to be connected within a network. ${ }^{5,26}$ For RDs in Europe, the most important network is EuroBioBank, consisting of 22 countries, which contains approximately half a million samples of 500 diseases, with an annual increase of 1300 samples. EuroBioBank provides samples in a wide geographic region and enables genetic research, gene therapy and drug toxicity testing, or development of diagnostic and therapeutic biomarkers. Recently, EuroBiobank has joined to RDConnect platform, a European research project, whose ultimate goal is to link patients registers, biorepositions and clinical data to RDs. ${ }^{27}$

Pharmaceutical companies also use biobanks in the development of drugs for RDs. As an example is Rare Disease Hub (RD-HUB), the central repository database of RDs that provide access to samples and associated clinical data of patients. This kind of co-operation has been the backbone for 30 years, and have resulted in the development and marketing authorisations for more than 400 drugs for RDs. In clinical trials of RDs, DNA samples are used to explore genetic polymorphism, genotype/ phenotype relations, then serum and plasma to identify new biomarkers drug efficacy monitoring, while cell and tissue culture make investigation of pharmacodynamics possible. ${ }^{5,24,26,27}$

However, to overcome the problem in conducting clinical trials due to the small number of patients and their samples, "omic" technology (genomics, proteomics, transcripts, metabolomics) are employed on high quality samples of biological material. The "omic" technologies in RDs make possible genome analysis, determination of proteins and metabolites profiles in a particular tissue / cell, detection of diagnostic and therapeutic biomarkers. ${ }^{28}$

Based on the aforementioned, biobanks for RDs are facing with a number of challenges, additionally to required quality of biological material. In the future there must be developed system that will connect with patient registers and their clinical data to facilitate location and exchange of research samples, and secure patient privacy in accordance according to ethical and legal provisions in different countries. ${ }^{27}$

\section{Conclusion}

Clinical trials in RDs around the world face problems of feasibility, constraints in patients recruitment, different regulatory requirements, and ethical issues. The design of clinical trials for RDs therefore are adapted to the specific indication and use of surrogate markers for outcomes assessment. One of the opportunities to access to drugs for RDs is within CUPs, when patients who do not meet defined criteria for participation in a clinical trial may receive a treatment. The promising option for the development of drugs for RDs includes research of diagnostic and therapeutic biomarkers in tissue samples stored in biobanks.

\section{References}

1. EURORDIS. Rare diseases in Europe. About rare diseases 2014. https://www.eurordis.org/content/what-raredisease [Accesed 1 March 2018].

2. Bolignano D, Pisano A. Good-quality research in rare diseases: trials and tribulations. Pediatr Nephrol 2016 31: 2017.

https://doi.org/10.1007/so0467-016-3323-7

3. European Medicines Agency. Science medicines health. http://www.ema.europa.eu/ema/ of subordinate documents. [Accesed 1 March 2018].

4. U.S. Food and Drug Administration (FDA). Protecting and promoting your health. http://www.fda.gov/ RegulatoryInformation/Legislation/ of subordinate documents. [Accesed 1 March 2018].

5. Graham C, Mlster C, Baynam G, Bushby K, Hansson M, Kole A, et al. Current trends in biobanking for rare diseases: a review. J Biorep Sci Applied Med 2014; 2:49-61. https://doi.org/10.2147/BSAM.S46707

6. Rose K. New Drugs for Rare diseases in Children. Clin Therap 2017; 39:246-252.

https://doi.org/10.1016/j.clinthera.2017.01.012 PMid:28161117

7. Stuart A Bell, Catrin Tudur Smith. A comparison of interventional clinical trials in rare versus non-rare diseases: an analysis of ClinicalTrials.gov, Department of Biostatistics, Liverpool, Orphanet J Rare Diseases, 2014; https://doi.org/10.1186/s13023-014-0170-O

8. Hall AK, Ludington E. Considerations for successful clinical development for orphan indications. Expert Opinion on Orphan Drugs 2013; 1(11): 847-850. https://doi.org/10.1517/21678707.2013.847786

9. Kuerner T. Essential rules and requirements for global 
clinical trials in rare lung diseases: A sponsor's standpoint. Resp Invest. 2015; 53: 2-6.

https://doi.org/10.1016/j.resinv.2014.09.001

PMid:25542597

10. Augustine EF, Adams HR, Mink JW. Clinical Trials in Rare Disease: Challenges and Opportunities. J Child Neurol, 2013; 28: 1142-1150.

https://doi.org/10.1177/0883073813495959

PMid:24014509

PMCid:PMC3964003

11. Gagne J, Thompson L, O'Keefe K, Kesselheim A. Innovative research methods for studying treatments for rare diseases: methodological review. BMJ 2014;349:g6802. https://doi.org/10.1136/bmj.g6802

12. Spineli LM; Jenz E, Grossenning A, Koch A. Critical appraisal of arguments for the delayed-start design proposed as alternative to the parallel-group randomized clinical trial design in the field of rare disease. Orphanet $\mathrm{J}$ Rare Dis 201712:140 https://doi.org/10.1186/s13023-017-0692-3

13. Williamson SF, Jacko P, Villar SS, Jaki T. A Bayesian adaptive design for clinical trials in rare diseases. Comput Stat Data Anal.2017;113:136-153. https://doi.org/10.1016/j.csda.2016.09.006

14. European Medicines Agency Compassionate use. http:// www.ema.europa.eu/ema/index.jsp?curl=pages / regulation/general/general_content_ooo293.jsp[Accesed 1 March 2018].

15. EURORDIS Can anyone access medicines on a compassionate basis https://www.eurordis.org/content/ can-anyone-access-medicines-compassionate-basis [Accesed 1 March 2018].

16. EURORDIS. Main characteristic of CUPs in different EU Member States. https://www.eurordis.org/content/maincharacteristics-cups-different-eu-member-states [Accesed 1 March 2018].

17. Hyry HI, Manuel J, Cox TM, Roos JCP. Compassionate use of orphan drugs. Orphanet J Rare Dis 2015;10:100. https://doi.org/10.1186/s13023-015-0306-x

18. Žnidar I, Collin-Histed T, Niemeyer P, Parkkinen J, Lauridsen AG, Zarina S, et al. The European Gaucher Alliance: a survey of member patient organisations' activities, healthcare environments and concerns. Orphanet J Rare Dis.2014;9:134. https://doi.org/10.1186/s13023-014-0134-4

19. Gianuzzi V, Devlieger H, Margari L, Odlind VL. The ethical framework for performing research with rare inherited neurometabolic disease patients. Eur J Pediatr. 2017; 176:395.

https://doi.org/10.1007/soo431-017-2852-9

PMid:28093642

PMCid:PMC5321701

20. Krzysztof Borski. Ethical issues in rare diseases. Department of Nutrition Hygiene. Poland. Dev Period Med. 2015;XIX,4:533-535.

21. Medić B, Todorović Z, Savić Vujović K, Stojanović R, Prostran M. Oboljeli od rijetkih bolesti kao vulnerabilni ispitanici u kliničkim studijama, JAHR 2013; 4:715-724.

22. Krajinović D, Arsić J. Etička pitanja u pedijatrijskim kliničkim studijama: izazovi i problemi kod pacijenata $\mathrm{s}$ rijetkim bolestima. JAHR 2014; 5:277-389.

23. Hallmans G, Vaught JB. Best practices for establishing a biobank. Methods Mol Biol. 2011;675:241-26o https://doi.org/10.1007/978-1-59745-423-0_13 PMid:20949394

24. Kinkorová J. Biobanks in the era of personalized medicine: objectives, challenges, and innovation: overview. EPMA J. 2016;7:4. https://doi.org/10.1186/s13167-016-0053-7 PMid:26904153 PMCid:PMC4762166

25. Biobanking and BioMolecular resources Research Infrastructure (BBMRI-ERIC). http://www.bbmri-eric. eu/BBMRI-ERIC/about-us/ of subordinate documents. [Accesed 1 March 2018].

26. EuroBioBank. European network of DNA, cell and tissue banks for rare disease. http://www.eurobiobank.org/en/ information/info_institut.htm of subordinate documents. [Accesed 1 March 2018].

27. Rubinstein YR, Posada de la Paz M, Mora M. Rare Disease Biospecimens and Patient Registries: Interoperability for Research Promotion, a European Example: EuroBioBank and SpainRDR-BioNER. Adv Exp Med Biol. 2017;1031:141-147.

https://doi.org/10.1007/978-3-319-67144-4_7 PMid:29214569

28. Gülbakan B, Özgül RK, Yüzbaşıŏlu A, Kohl M, Deigner H-P, Özgüç M. Discovery of biomarkers in rare diseases: innovative approaches by predictive and personalized medicine. The EPMA Journal. 2016;7(1):24.

https://doi.org/10.1186/s13167-016-0074-2 PMid:27980697 PMCid:PMC5143439 


\section{Klinička ispitivanja lijekova i značaj banaka biološkog materijala u rijetkim bolestima}

\section{SAŽETAK}

Rijetke bolesti ("orphan diseases") predstavljaju 5000-8000 oboljenja, niske prevalence i najčešće genetski uslovljene etiologije. lako se većina ovih bolesti manifestuje u ranom djetinjstvu, mnoge se dijagnostikuju kod odraslih, čak i kod osoba starije životne dobi. Zajedničke karakteristike, kao što su ozbiljnost kliničke slike, to da su onesposobljavajuća i životnougrožavajuća stanja, uz nedostatak specifičnog lijeka, čini liječenje rijetke bolesti značajnim javno-zdravstvenim problemom. Premda randomizovana, kontrolisana klinička ispitivanja predstavljaju najidealniji dizajn istraživanja novih lijekova i cilj ovog rada je bio da u kontekstu rijetkih bolesti prikažemo otežavajuće okolnosti sa kojima se suočava razvoj tzv. orphan drugs. U obzir smo uzeli pregled naučnih publikacija objavljenih u PubMed/Medline, za period 2010. do 2017. godina, a koje se tiču kliničkih ispitivanja i etičnosti u rijetkim bolestima, te primjeni “omics” tehnologija u istraživanju uzoraka tkiva deponovanih u bankama biološkog materijala. U ovom preglednom radu smo prikazali najznačajnije barijere u provođenju ispitivanja lijekova za rijetke bolesti, kao i glavne, alternativne dizajne kliničkih ispitivanja, a koja imaju za cilj smanjenje broja regrutovanih pacijenata, uz povećanu mogućnost dobijanja inovativnih lijekova što većeg broja ispitanika. Dalje, prikazali smo mogućnost pristupa inovativnim lijekovima van kliničkih ispitivanja, kao i načela etičnosti koja bivaju ugrožena učešćem oboljelog u ispitivanju. Savremene tehonologije u molekularnoj biologiji će omogućiti razvoj precizne medicine ("precise medicine"), usmjerene na identifikaciju najboljeg terapijskog cilja, zavisno od genetskih i epigentskih faktora kod oboljelog. Upravo zbog toga banke biološkog materijala za rijetke bolesti (biorepozitorijumi) imaju veliku značaj u čuvanju i distribuciji uzoraka tkiva, u istraživanjima dijagnostičkih biomarkera i razvoju novih lijekova.

Ključne riječi: rijetke bolesti, "orphan drugs", klinička ispitivanja, etika/etičnost, biobanke 